\title{
Háger Tamás*: A magyar büntető igazságszolgáltatás az államalapítást követő első századokban a római és az európai jogfejlődés tükrében
}

\author{
Debreceni Jogi Mühely, 2014. évi (XI. évfolyam) 1-2. szám (2014. június 30.)
}

\section{Bevezetés}

Amint a latin mondta, a jog az országok talpköve. Az államszervezet, az államhatalom müködése elképzelhetetlen jog nélkül. A magyar jogfejlödést, ide értve a civiljogi, de különösen a büntetöjogi normákat, már a középkor elején olyan királyi dekrétumok dokumentálják, melyek nem csupán anyagi jogi, hanem eljárási szabályokat is tartalmaztak. A magyar állam és jogfejlődés elválaszthatatlan az európai jog alakulásától. Rómának, a modern jog bölcsőjének hatása, különösen a polgári jogi viszonyok tekintetében a mai napig érvényesül, gondoljunk itt különösen olyan kötelmi és örökjogi szabályokra, melyek évezredek múltán is meghatározzák a jogi szabályozást, ugyanakkor a büntetőjogi hatásokat sem lehet lebecsülni. Európa hatása tehát vitathatatlan a hazai jogra, különösen a nyugati civilizáció és jogrend, szerves összefüggésben a kereszténység felvételével jelölt ki olyan utat, melyet, ha az évszázadok során jelentős eltérésekkel is, de követett a hazai jogfejlődés. Megállapíthatjuk ezt annak ellenére, hogy a büntető perjog tételes szabályainak kodifikálására csak a XIX. század végén került sor. A magyar állam - és jogfejlődés korai szakaszának szabályai, ha nem is érvényesülnek az újkori eljárásjogban, az vitathatatlan, hogy az államszervezet és a bírósági rendszer fejlődése által az anyagi és eljárásjogi szabályok nem választhatók el élesen a történeti elözményektől. Tanulmányomban a római és a középkori európai jogfejlődés hatásának tükrében a büntető igazságszolgáltatás, különösen a büntetőeljárás szabályainak kialakulásával kapcsolatos egyes fontos jogintézményeket kívánom bemutatni az Árpád-házi királyok korát érintve, annak előrebocsátásával, hogy az anyagi büntetőjog és a perjog szervesen összefügg, hiszen a jogalkalmazó a büntető anyagi jogszabály megsértését vizsgálja az eljárásban. Ezt támasztja alá, hogy évszázadokon át a nyugat-európai jogfejlödésben az anyagi és az alaki büntetőjogot rendszerint egy törvénykönyvben szabályozták. Mindez tapasztalható Árpád-házi királyaink törvényeiben is, ahol a törvénysértés és a felelősségre vonás gyakran egy normában jelent meg.

\section{Gondolatok a büntetőeljárás fogalmáról és céljáról}

A társadalom, majd az állam létrejötte után az azok rendje ellen vétő személyt meghatározott, kezdetben szakrális formaságok mellett felelösségre vonták. Kezdetben a büntetés célja a megtorlás volt, majd később a történelem fejlődése során megelözéssé enyhült.

A büntetőeljárás történeti fejlődésének vizsgálata előtt fel kell tennünk a kérdést, hogy mit is jelent a büntetőeljárás. A büntetőper célja nem vitásan a társadalom, állam rendjét megsértő személy felelősségre vonása, megbüntetése, Liszt nyomán a büntetés által a megbillent jogrend helyreállítása.[2] Amint Angyal Pál kifejtette, a büntetőeljárás olyan, egymással láncolatszerüen összefüggő és előrehaladó cselekmények, melyeket az állam szervei és bizonyos esetekben magánszemélyek az állam büntetőjogának megvalósítása érdekében foganatosítanak.[3]

Az eljárás célját és folyamatjellegét hasonlóan fogalmazta meg majd egy évszázaddal később Erdei Árpád is, álláspontja szerint ugyanis ,a büntetőeljárás a büntetőjogi felelősség eldöntésére irányuló, jogilag szabályozott folyamat”.[4] A meghatározandó fogalom genus proximumának megjelölése vitathatatlan és szemléletesen rámutat az eljárás folyamatjellegére, céljára. A több évszázadot felölelő jogfejlődés minden lényeges elemére 
nem térhetek ki, de az államalapítást követő századok törvénykezésének azon fő pontjait, melyek meghatározták az ítélkezési rendszer, az igazságszolgáltatás és különösen a büntetőper fejlődését, a római jogi és európai hatásokra is rámutatva, vizsgálat alá kívánom vonni s ahol a jogintézmény jellegéből adódóan lehetőség van rá, a jelenleg hatályos eljárási rendelkezések tükrében is megkísérlem vázlatosan elemezni az államalapítást követő első századok büntető igazságszolgáltatását.

\section{A büntető igazságszolgáltatás római jogi gyökerei}

Az európai, így a magyar jogfejlődésre is, máig hatnak a római jog klasszikus jogintézményei, mindez különösen a civiljogra, a szerződéses viszonyokra, az örökjogra igaz, de már megjelentek az ókorban is olyan büntető anyagi jogi kategóriák, melyek hatással voltak Európa, ekként hazánk jogfejlődésére is. Az ókori birodalmak hanyatlása után, a középkor kezdetén ugyan a korábbitól eltérő irányban változott a jog, a római jog évezredes nyomainak felidézése sohasem lehet azonban haszontalan egy büntető jogtörténeti tanulmányban sem.

\subsection{Alapvetések az ókori Róma büntető igazságszolgáltatásáról}

Mikor Róma a történelem színpadára lépett, még monarchia volt, a királyokat azonban a Kr.e. 6. század végén elüzték és köztársaságot alapítottak. A jog kezdetben íratlan szokásjog volt, melyet szájhagyomány útján adtak tovább a nemzedékek. A decemvírek által kidolgozott normagyüjtemény, a XII táblás törvény tekinthető a ma ismert római jog kezdetének. A Kr.e. 451. körül született törvény az anyagi jogi szabályok mellett eljárási normákról is rendelkezett.[5] A törvény eredeti szövege nem maradt ránk, de a történetírás megőrizte lényegi elemeit. Ha a teljes tartalma nem is rekonstruálható, céljai, iránya azonban meghatározhatók a rendelkezésre álló források alapján.[6] Az ősi társadalom fejlettségén már túllépö, azonban még primitív államszervezet igen korán törekvéseket tett a magánbosszú visszaszorítására, mégpedig a talio (szemet szemért, fogat fogért) elv[7] bevezetésével, valamint részben a vagyoni, tarifális compositio megállapításával.[8]

A Kr.e. V. századtól a XII táblás törvény egyes kriminális jellegü normái megváltoztak. A marasztalt adós hitelezője többé már nem volt jogosult az adós megölésére, hanem lehetőséget kellett teremtenie arra, hogy a tartozást kényszermunkával ledolgozza. A köztársaság korában a jogot nem is annyira a jogalkotás és jogértelmezés, hanem a különféle jogsegélyek fejlesztették, melyben nagy szerepet kapott a preator, aki ugyan az állította, hogy nem alkot jogot, nem vitás azonban, hogy valójában a jogsegélyek által bizonyos formában jogalkotás is köthető tevékenységéhez.[9] Nem mondhatjuk teljesen igaznak ezért az ismert mondást, miszerint ,preator ius facere non potest”, mely azt fejezi ki, hogy a preator csak alkalmazza és nem alkotja a jogot.

Már a primitív római államban kialakult a büncselekmények két fő kategóriája, a magánüldözés, valamint a közüldözés alá eső bűncselekményeké (delictum, illetve crimen). A magánüldözéses büncselekmények elkövetésekor az állam csak a sértett vagy annak családja, jogutódjai kívánságára lépett fel a bünügyben.[10] A magánüldözéses büncselekmények kategóriája fennmaradt a modern kor büntetőjogában is, gondolhatunk itt a magánindítványra üldözendő, illetve magánvádas büncselekményekre.

A köztársaság korában indult meg az a folyamat, mely a crimenek körét a delictumok terhére tágította. Eredetileg csak két criment ismertek, a hazaárulást (perduellio) és a gyilkosságot (parricidium). A köztársaság utolsó századában, a Sulla-féle büntetőjogi reform a büntetőbíróságok (quaestiones) újjászervezése mellett a közüldözéses büncselekmények számát növelte, e körbe vonva például az állami főszervek megsértését, az állami tulajdon eltulajdonítását, vagy a pénzhamisítást. 
A klasszikus korban a császári per során a császár által kinevezett hivatalnokbíró a magánüldözés alá eső büncselekményeknél is elrettentő büntetéseket szabott ki.[11]

A posztklasszikus jog lazított a crimenek és delictumok közötti határon, egyre több büncselekmény vált közüldözés tárgyává, de a kettősség a római jog egész fejlődése során fennmaradt, s mint utaltam rá, továbbél a modern büntetőjogban is.

A delictumok magánjellege a klasszikus kortól egyre inkább megszilárdult, a régi, magánbosszún alapuló büntetéseket kötelezően váltotta fel a compositio rendszere, a pénzbüntetés előtérbe kerülése, mely az áruszemlélet behatolását világítja meg a deliktuális felelősség rendszerébe. E pénzbüntetés azonban nem tekinthetö azonosnak a modern büntetőjog vagyoni jellegü joghátrányával. Magában foglalta ugyanis a sértett kárának megtérítését, a pénzbüntetés teljes egészében a sértettet vagy jogutódját $\mathrm{s}$ nem az államot illette, a szankciót pedig rendszerint vagyonjogi ügyekben eljáró bíróság szabta ki. Ebből is következik, hogy a római jogban kialakított büncselekmény fogalom és a modern jog büncselekményfogalma nem fedik le egymást.[12] A modern büntetőjog is nagy figyelmet fordít ugyan a sértett helyzetének reparálására, kárának megtérítése, de a büntetőperben a kárigény érvényesítését célzó adhéziós eljárás elválik a büntetéstől, és járulékos kérdésként jelenik meg a büntetőügyben.

\subsection{Anyagi jogi szabályok és eljárásjogi érvényesítésük}

A büntető anyagi jogi szabályok önmagukban sohasem érvényesülhetnek, mert szükséges egy olyan eljárás, melynek keretében a jogsértéssel járó következmények realizálása megtörténik. Ez a procedúra a büntetőeljárás, melyben a bünt elkövető felelősségre vonására sor kerül. Miként is folyt mindez az ókori Rómában? A két fö büncselekmény kategóriát külön-külön, eltérő szabályok szerint folyó eljárás kísérte. Tekintsük át mindezek előrebocsátása után elsőként a deliktuális kereseteket, majd a közüldözéses büncselekmények eljárását.

\subsubsection{A delictumok és az azokhoz kapcsolódó keresetek}

Elödlegesen arra szükséges kitérni, hogy milyen delictumokat ismert a római jog. Klasszikus és máig büntetendő cselekmény a lopás (furtum). Róma joga nem csak a dologlopást (furtum rei), hanem a haszonlopást (furtum usus) és birtoklopást (furtum possessionis) is szankcionálta. A dologlopás mellett a haszonlopás csalásként a modern jogban is jelen van. A törvény megkülönböztette a lopást aszerint is, hogy az elkövetöt tetten érték (furtum manifestum) , avagy sem (furtum nec manifestum). A tetten ért éjjeli tolvajt, vagy a fegyveresen ellenálló elkövetőt, a károsult magánbosszújának adták át, a sértett őt megölhette. Ha a tettenérésre nappal került sor, és a tettes fegyverrel nem állt ellen, életét nem oltották ki, büntetése megkorbácsolás és szolgaságba adása volt.[13]

Delictumként ismerte a római jog a személysértést (iniura) is.[14] A személysértés egyik szabálya szerint, ha valaki más tagját törte, és nem egyezett ki vele, hasonló büntetéssel sújtották, mely szabályban egyértelmüen a talio elv jelenik meg. Egy másik tényállás akként fogalmazott, hogy ha valaki kézzel vagy bottal szabad ember csontját törte, pénzbüntetéssel kellett sújtani. A praetor-i jogsegély kialakulásával és megerősödésével e szabályok elavultak. A klasszikus jog dolgozta ki részletesebben az iniuria tényállását. Az actio iniuniarum populáris, és a sértett életére korlátozott kereset volt.

A római jog ismerte a rongálást (damnum iniuria datum), mely a dolgot ért kárral járt. Dolognak minősült a rabszolga is, akinek, vagy más barmának megölése esetén a tettesnek büntetésként anyagi jóvátételt kellett fizetnie.[15] 
A rablás (rapina) is delictumnak minősült. A modern jog által összetett büncselekménynek nevezett rapina részben a furtumból, részben az iniuriából alakult ki s él máig a súlyos büncselekményre irányadó szabály, hogy a rablás egyrészt erőszakból, vagy minősített fenyegetésből, azaz a kényszerítésből, másrészt az idegen dolog jogtalan elvételéből, a lopásból áll.[16]

A sírhely megrongálása (sepulchrum violatum) pénzbüntetést vont maga után.

A hitelezők megkárosítása a preatori edictum folytán szintén delictum volt, e cselekményt az követte el, aki vagyontárgyait a végrehajtás elöl elidegenítéssel szándékosan elvonta.[17] A gazdasági élet és a társadalmi, állami viszonyok magas szintű fejlettségét jelzi, hogy a római jog már ilyen speciális tényállást is szabályozott, mely a modern jogban is megjelenik csődbüncselekményként.

A deliktumokból származó kötelem jogot adott a sértettnek, vagy jogutódjának, hogy a kártérítést is magában foglaló pénzbüntetést követeljen a sérelmére jogellenes cselekményt elkövetővel szemben. Ez volt a római pénzbüntetés, a poena.[18] A pénzbüntetés kikényszerítésére irányuló büntetőkeresetet actio poenales-nek nevezték. A büntető jellegü keresetek fö jellemzője volt, hogy csak a tettes ellen voltak megindíthatók, a jogutódra ekként a joghatások nem terjedtek ki. E klasszikus büntetőjogi elv a modern jog része is, a büntetőjogi joghátrány, szemben egyes civiljogi kötelmektől, az elkövető halála után örököseit, jogutódjait nem terheli. A jogutódlás (hereditas) kapcsán jegyzendö meg, hogy az öröklés a hátrahagyott vagyon átszállásának folyamata. Magát az egyetemes jogutódlást is öröklésnek nevezzük. A poenális actiók a sértett halála után jogutódjaik által is megindíthatók voltak, mint a közönséges keresetek. Kivétel volt azonban, amennyiben a kereset célja személyes jellegü elégtétel volt (actio vindictam spirans), mert ekkor a sértett halála megszüntette az actióra való jogosultságot.

Büntetőkeresetet kivételesen nem csak a sértett vagy jogutódjai, hanem érintettségétől függetlenül bármely polgár indíthatott, ezt nevezték populáris actiónak. Példaként hozható fel e körben a sírhely meggyalázója elleni kereset (actio de sepulchro violato). A modern jogban az officialitás megszilárdulása mellett már természetes, hogy bármely személy feljelentése alapján, a törvényben írt előfeltételek megvalósulásakor a hatóság a büntetőeljárást lefolytatja.

A római jog ismerte az un. vegyes kereseteket (actio mixta) is, melyekben a megtérítésre irányuló igény is benne foglaltatott a büntetőigényben s ez kizárta külön megtérítési actió indítását. Említést kell továbbá tenni a noxalis keresetekről, melynek helye volt a családfö, illetőleg a rabszolgatartó ellen, ha a családtag, vagy a rabszolga követte el a delictumot. [19] A pater familias ekként felelt családtagjai és rabszolgái bünös cselekedeteiért is, mely elv a modern büntetőjogban a társadalmi rendszer jelentős átalakulása folytán értelemszerüen már nem érvényesül.

\subsubsection{A crimenek és büntetésük}

A közüldözéses, a modern jog megnevezésével közvádas büncselekmények fejlődése szorosan összefüggött Róma állami és társadalmi rendjének változásával, alakulásával. Ebből eredően más volt a jellege a korai köztársaság, a késői köztársaság, a principatus és a dominatus korszakában a közüldözés alá vont büncselekményeknek és büntetésüknek.

A korai köztársaság idején a már hivatkozottak szerint a két ősi crimen a XII táblás törvény szerint az emberölés és a hazaárulás volt. Az emberi élet bűnös kioltása ősidők óta következményeket von maga után, mint ahogy ma is az egyik föbenjáró bün. A tüzveszélyokozás, a titkos éjszakai összejövetelek, a bíró megvesztegetése, bizonyos mágikus tevékenységek szintén crimennek minősültek. A tüzveszélyokozás, mint közveszély okozása 
hatályos büntető törvényünkben is büntetendö, mint ahogy a vesztegetés is.[20] A XII táblás törvény általában csak a halálbüntetést jelölte meg szankcióként, bizonyos esetekben azonban volt lehetőség pénzbüntetés alkalmazására, akár vesszőzéssel összekapcsoltan.[21] A mai értelemben vett szabadságvesztés az ókori Rómában nem létezett. Börtönjellegü építmények ugyan voltak, viszont azok nem tartós, büntetésként történő elzárásra, hanem a kivégzés előtt a foglyok őrzésére szolgáltak. Megjegyzendő, hogy az adósrabszolgaság nem tekinthető szabadságvesztésnek, mert az vagyoni célt szolgáló magán jellegü fogság volt, amit a hitelező s nem az állam hajtott végre.

A crimenek a késői köztársaság idején részben átalakultak, részben bővültek. Új közüldözéses cselekményként jelentek meg a politikai büncselekmények (crimen maestitas), a választási vesztegetés (ambitus), vagy hamisítások.[22] Külön bíróság ítélt az orgyilkosságot és a méregkeverést elkövető felett.[23] Bővült a büntetések palettája is, a halálbüntetésen és a pénzbüntetésen kívül vesztegetésnél bevezették a hivatal- és senatus tagság viselésére való képtelenséget, egyes esetekben a számüzést, illetve a vagyonelkobzást. Az új büncselekmények és szankciójuk jól tükrözi a római államszervezet és jog magas szintü fejlettségét. A korrupciós büncselekmények és speciális joghátrányai a modern jognak is állandósult részei.

A principatus korában ugyan még létesültek questiok, például a házasságtörés ügyében ítélkező bíróság[24], azonban mindinkább az új perrend, a császári extraordinaria cognitio érvényesült, mely a crimenek tartalmát is módosította. A crimen maestitas e korszakban már nem a populus Romanus biztonsága elleni büncselekményt, hanem a császár személye ellen irányuló felségsértést jelentett. Az új, császári perrend lehetővé tette, hogy a bíróság kötetlenül, a legcélravezetőbb büntetést alkalmazza.

A dominatus idején kezdetben nem történtek jelentős változások a közüldözéses cselekmények terén, a keresztény császárság korában azonban az új ideológiából eredően több új büncselekményt alkottak, mint az eretnekség, a nőszöktetés vagy a vérfertőzés. A dominatus, eltérően a principatustól, kötött büntetési rendszert alakított ki. A különleges halálbüntetések sorát (keresztre feszítés, megégetés, vadállatok elé vetés) vezették be és terjesztették ki a bűncselekmények szélesebb körére. Általános büntetéssé vált továbbá a kényszermunka a bányákban vagy közmunkánál. A jusztinianuszi jog enyhített csak némiképp e szigorú büntetési rendszeren. [25]

Összegezve, megállapíthatjuk, hogy a római jogban már megjelentek azok a büntetőjogi alapintézmények, fogalmak, melyek az európai jogfejlődést meghatározták. Róma joga nyilvánvalóan továbbélt a középkorban is, ha az államrend jellege és a vallomás folytán módosult formában is.

\subsubsection{A római perjog sajátosságai}

A királyság és a köztársaság korában tiszta vádrendszer épült ki. A vádat, mely nélkül eljárásnak nem volt helye bizonyos esetekben (proditio, perduellio), rendszerint a duum viri perduellionis, illetve questores parricidii képviselték. A védelem nem esett korlátozás alá, a vádolt védő segítségét igénybe vehette. A bizonyítás során a szabad mérlegelés érvényesült.

A bíráskodást kezdetben maga a nép végezte, majd a Kr.e. II. századtól a már említett quaestiok. A tárgyalás nyilvános volt, a felek nyilatkozatai után a questio tagjai absolvo, condemno vagy non liquet feliratú táblácskákkal szavaztak az ügyben. A szavazás eredményén alapuló határozatot az elnök hirdette ki. A vádolt felelősségéröl szólt a döntés, magáról a büntetésről azonban nem, mert a törvények abszolút büntetési tételeket írtak elö.

A császári korban változás következett be. A vádjog a bírói hatalom erősödésével korlátozottabb lett, a védelem joga azonban nem szenvedett csorbát. A bírói teendőket a 
császárkor elején még a questiok, később a császári tisztviselők látták el. A nyilvánosság korlátozottabb volt a köztársaság ítélkezéséhez képest. A tárgyalásról jegyzőkönyvet vettek fel, melynek célja az volt, hogy sérelmes döntés esetén a császárhoz előterjesztett fellebbezés megfelelő felülbírálatára mód legyen.[26] Látható, hogy már az ókori Róma joga ismert olyan alapvető, modern büntetőeljárási jogintézményeket, mint a vád, a védelem, valamint a jogorvoslat.

\section{A középkori európai büntetőjog fejlödésének alapjai és hatása a magyar igazságszolgáltatásra}

A Kr.u. a VI-X. századra tehető korai európai feudalizmusban a germán, szláv, muzulmán, balkáni jogfejlődésnek lehetünk tanúi. A római birodalom bukása után, a meglehetősen sötétnek festhetö középkor hajnalán az államszervezet és a jog még századokig nem érte el a római fejlettséget, de hamarosan megindult azon európai jogfejlődés, mely a középkori magyar büntető igazságszolgáltatást is meghatározta. A rendi állam megszilárdulásával, a virágzó feudalizmus korában a frank jog hatása érvényesült Európa más államaiban is. A frank eredetű „Bann jog”, az uralkodók által kibocsátott edictumok, decretumok [27] alapul szolgáltak később más nemzet uralkodóinak, így a magyar királyoknak is a jogalkotásához.

A középkori germán népjogok, eltérően a római jogrendszertől, sokáig nem különböztették meg a polgári és a büntetőeljárást, mely utóbbi lényegében nem volt más, mint a magánbosszú állami támogatása. Az eljárás formaszerű vádra indult meg, mellyel a sértett a vádlottat mannitio útján megjelenésre, nyilatkozattételre, a bíróságot pedig ítélethozatalra kényszeríthette. A tárgyalás nyilvános és szóbeli volt, a bizonyítás pedig formális, mely bizonyítás, eltérően a modern jogtól, nem a vádlót terhelte, hanem a terhelt joga volt tisztító eskü, eskütársak, istenítélet által. Rabszolga ellen tortúrát alkalmaztak. A tárgyalást a király küldötteként megjelenő bíró végezte, az érdemi döntést, a végítéletet azonban a nép, illetve tanácsa hozta meg. A korai középkor európai, különösen germán-frank jogfejlödése nem vitásan hatással volt az államalapítást követő századokban hazánk büntetőjogára is. A későbbiekben részletezettek szerint a bizonyításban, perjogunkban is megjelentek az istenítéletek, az eskü, mely szakrális jellegü bizonyító eljárások formai volta kétségtelen. Az ítélkezésben, hasonlóan a nyugat-európai joghoz, a király, majd később megbízott föméltósága müködött közre.

A frank jog továbbfejlődését jelentette, hogy a bírónak a javaslattételre irányuló joga hét jogtudó személyre (rechimburgi) szállt át. Nagy Károly[28] e személyeket már élethosszig nevezte ki a bíró mellé, megteremtve ezzel a Shöffen-bíróságokat és a lényegében az inkvizíción nyugvó Rüge eljárást. A Rüge királyi küldöttként időről időre felkereste az egyes községeket és felhívta a szavahihető embereket, hogy eskü alatt tegyenek jelentést a súlyosabb büncselekményekről, illetve válaszoljanak a küldött kérdéseire. A beszerzett információk alapján a Rüge indította meg az eljárást, aki a vád helyébe lépett, mindez pedig a hivatalból való eljárás megindításához vezetett, áttörve a korábban uralkodó elvet, hogy vád nélkül nincs eljárás. Közrehatott ebben az állam részéröl annak felismerése, hogy a súlyosabb büncselekményeknél - mint a lopás, rablás, kártétel, szemérem elleni cselekmények (homines criminosi) - a felelősségre vonást nem lehet függővé tenné attól, hogy a sértett kíván-e vádat emelni vagy sem. A Rüge-eljárás nyilvánvalóan az officialitás térnyerését jelzi a középkori büntetőeljárásban, kifejezve azt is, hogy az igazságszolgáltatás a király joga. Érdemi előrelépést jelentett, hogy a Shöffen-bíróság nem a régi, formális bizonyítás alapján ítélkezett, mert az eskütársak helyére valódi tanúk léptek, továbbá a tetten ért elkövetö ellen is le kellett folytatni az eljárást. Nagy Károly halála után a Rüge eljárás vesztett jelentőségéből, a formalizmus újból megjelent, a bizonyítás során gyakran kínvallatást végeztek, a bíráskodást sok helyen a hübérurak, magánosok ragadták magukhoz. 
A büntetőeljárás fejlődését a római és kánoni eljárásjog egyes intézményeinek recipiálása, valamint a glosszátorok és praktikusok által kidolgozott nyomozórendszer is meghatározta. A kánoni eljárás, ha büncselekmény volt a tárgya, a vádelven alapult, azonban ha vétek miatt indíttatott, valamint ha köztudomású büntettekről (notoria, manifesta) volt szó az eljárás hivatalból indult meg s a nyomozó elv szerint folytatták le. Az eljárásnak ezen utóbbi formája a synodalis bíróságok elött a Rüge eljárás mintájára alakult ki. A püspök, illetve küldötte elött a hívek eskü alatt feljelenteni tartoztak a súlyos büncselekményeket elkövetőket, akik felett ezt követően a sydonalis bíróság ítélt. Az eljárást III. Ince pápa decretalisai rendezték, melyeket a IV. lateráni zsinat szentesített 1215-ben.[29] Az inkvizíció sajátosan kapott szerepet, mert rendszerint az eljáráshoz kellett vád, azonban hitelt érdemlö feljelentés, köztudomás, egyházi személy elleni feljelentés, rossz hír esetében az eljárás hivatalból indult meg. A bíró nem volt kötve a felek indítványához, hivatalból kellett beszereznie a bizonyító anyagot. A kánoni eljárás jellemzője volt az írásbeliség, a nyilvánosság korlátozott volta, de a védelem szabadsága biztosítva volt. A kánoni per különös jelentőségét az adja, hogy a római eljárás bizonyítási rendszerének kiépítésével sokáig ellenállt a formális alapokra épülő germán bizonyító rendszernek. Később a kánoni eljárás is átvette a germán bizonyító eszközöket, mint a tortúra, illetve az istenítélet, mely mindenképp visszalépésnek tekintendő a jogfejlődésben.

A klasszikus nyomozó rendszert az olasz glosszátorok és praktikusok alakították ki a Kr. u. XIII-XV. században. E rendszer fö jellemzői, hogy az eljárás kivétel nélkül minden büncselekményre való alkalmazásban köztudomás alapján indult meg, a bizonyító eljárás része volt a tortúra, a bíró korlátlan eljárási jogokkal rendelkezett, a vádlott pertárgyként szerepelt, a védelem kizárásával vagy jelentős megszorításával folytatott eljárás titkos, közvetett és írásbeli volt, a bíró ex actis ítélt.

Nyugat-Európától eltérő büntető eljárási rendszer alakult ki Angliában a normannok által a frank területről 1066-ban áthozott Rüge-eljárásból. Ellenben míg a német jogterületen ezen eljárás a nyomozó rendszer kifejlődéséhez vezetett, addig Angliában a vádrendszer kialakulásának szolgált alapjául. [30]A sheriff közremüködésével folyó és esküdtbíráskodáson alapuló eljárás elemzése, tekintettel a magyar jogfejlődés eltérő irányára is, nem képezi a tanulmány tárgyát, szükséges azonban jelezni, hogy a germán alapok ellenére Britanniában a kontinentálistól jelentősen eltérő jogrendszer alakult ki.

Összességében megállapíthatjuk, az európai jogfejlődésnek a kontinentális ága gyakorolt befolyást a fiatal magyar állam első századaiban a büntető igazságszolgáltatásra. Kezdetben vádelvű volt ugyan az eljárás, de egyes büncselekményeknél a procedúra hivatalból megindult, emellett az ítélkezés királyi joga, vagy egyes bizonyító eljárások, mint az eskü, eskütársak, istenítélet, tortúra a frank-germán joghoz hasonlóan megjelent a magyar büntetö eljárásban is, majd az európai jogfejlődéshez hasonlóan a nyomozó elvü eljárás is szélesebb körben teret nyert.

\section{Büntető igazságszolgáltatás hazánkban az Árpád-házi királyok korában 5.1. A bírósági rendszer fejlődése}

A magyar állam létrejötte, a királyság megszületése érdemi változásokat hozott a büntető igazságszolgáltatásban a törzsi-nemzetségi társadalom jogviszonyaihoz képest. A büntető anyagi és alaki jog részletes kodifikálására ugyan még évszázadokig nem került sor, azonban elsősorban az államszervezetet és a bírósági rendszert már szórványosan törvényekben szabályozták, mely nyilvánvalóan meghatározó befolyást gyakorolt a bírói hatalomra, ezáltal magára a büntetőeljárás szabályaira is. A latin nyelven írt törvények eredetben nem maradtak 
fenn, későbbi korok jogtudósainak, történetíróinak feljegyzései által élték túl történelmünk viharos évszázadait.

Géza fejedelem és az erdélyi Zombor gyula Sarolt leányának fiát, a keresztelés elött Vajk nevü, a keresztségben Stephanus nevet kapó Istvánt 1000-1001 év fordulója táján koronázták magyar királlyá. Ezzel István megkapta a keresztény legitimációt a föhatalom gyakorlásához, az isten kegyelméből való uralkodás okleveleiben és törvényeiben is megjelent. Az állam létrejöttével, a kereszténység felvételével országunk végérvényesen az európai fejlödés útjára lépett, mely tükröződött a törvényhozásban, és az igazságszolgáltatásban is. Az Árpád-házi királyok alatt indult meg azon jogalkotás (királyi dekrétumok), melyek a bírósági rendszer és a büntető anyagi, valamint alaki jog alapjainak lerakását jelentette.

A büntetőeljárás fejlődéséhez szorosan hozzátartozik a bírói hatalom alakulásának kérdése, hiszen a bírói hatalommal feljogosított személy, szerv ítélkezésében jelentek meg a még évszázadokig nem kodifikált, de egyes forrásokban már töredékesen rögzített és a korai időszakban alapvetően szokásjogi alapokon nyugvó büntetőeljárás normái. A bírói hatalmat a királyság megalakulásától fogva a XVI. század elejéig alapvetően a király gyakorolta részben a királyi udvarban (in curia regia), részint a megyékben tartott ún. törvénynapokon, ahol általában már bevonták az ítélkezésbe az előkelőségeket is.[31] Szent István király érvényesítette elsőként az állam büntetőhatalmi igényét[32] és határozottan törekedett a szervezett nemzetségi igazságszolgáltatás háttérbe szorítására, melyet hüen tükröz a vérbosszú büntetendőségét elöíró rendelkezés.[33] A vérbosszú ezek után súlyos anyagi és egyházi következményekkel járt, a kemény és határozott királyi fellépés megfelelő záloga lehetett az önhatalom visszaszorításának, egyben az államhatalom megerősítésének, mert a magánháborúk, a vérbosszú, az önbíráskodás nyilvánvalóan anarchiához vezetve a fiatal állam alapjait ingathatta volna meg. E törekvés jegyében született I. István dekrétuma a kard kirántásának tilalmáról,[34] valamint a kardot rántó, de sebet nem ejtő bűnhődéséről is. [35] A vérbosszú visszaszorításánál, amint láthatjuk alapvető szankció volt a vagyoni joghátrány, melynek jelentős része a kincstárat és a sértetti rokonságot illette, de eljárásukért a bírák és a közbenjárók is részesültek a gyilkos vagyonát csökkentő aranypénzből. A magyar perjog fejlődésének már e korai szakaszában nyomon követhető, hogy a marasztalt elkövetőt sújtó büntetésböl eredő vagyon jelentős részét az állam szerezte meg, de megjelent már a sértetti kör kártalanítása is. A vagyon elvonása és állam részére juttatása, valamint a sértett reparálása a modern büntetőjognak is része. Természetesen az újkori büntetőeljárásban a bírák javadalmazása már nem az elkövetőre kirótt büntetésből fedezett, hanem szigorú szabályok szerint költségvetési forrásból származik, a terhelti vagyonrész ugyanakkor napjainkban is az államot illeti s nyilvánvalóan költségvetési bevételt jelent.

Az ügyek számának fokozatos növekedésével a király megosztotta ítélkező hatalmát a főméltóságokkal, így jutott bírói hatalomhoz először a nádor, aki utóbb 1342-ig önállóan ítélkezett a királynak fenntartott ügyek kivételével, majd az országbíró, később a kancellár (judices regni ordinarii).[36] Megállapítható, hogy a királyi udvarban már István király korában létrejött bizonyos munkamegosztás, amely során az uralkodó távolléte idejére ítélkezés céljára tartós megbízást adott. Alappal feltételezhető, hogy a nádorispán a király távollétében az udvarban ítélkezett és már ekkor önálló hatalommal bírtak az udvarnokok is az ítélkezés során. A hagyományok szerint I. István udvarbírót is tartott, aki az udvari népek azon csoportjainak ügyeiben döntött, amelyek nem tartoztak a nádorispán jogkörébe.[37]

A rendes bíróságok mellett kialakultak a vidéki bíróságok is, melyek eleinte csak a várjobbágyok s alsóbbrendủ szabadok felett ítélkeztek, majd utóbb a rendi különválás során, a XIII. században a vidéki bíróság szervezete is differenciálódott. Így jöttek létre a nemesek felett ítélkező megyei ítélőszékek (sedes judicaria), a külföldröl betelepedettek, majd utóbb általában a városok polgárai felett ítélkező városi bíróságok, mely fórumok a főbírákból és 
tizenkét esküdtből álltak (jurati cives), valamint a földesúri bíróságok (úriszékek), melyek a rabszolgák, utóbb általában a parasztok felett eleinte a földesúr személyében, majd tisztjei, az udvarbírák (comes curalis) útján döntöttek. Külön szervezettel bírtak bizonyos hozzájuk utalt ügyekben (uzsora, hamis eskü, hitszegés) mindenkire kiterjedő bírói hatalommal az 1222 után különös kiváltság alapján müködő szentszékek, a római katolikus egyház bíróságai, melyek a püspök elnöklete alatt a szentszéki ülnökökből alakultak s ítéleteik ellen az érseki, ettől pedig a római szentszékhez engedtek fellebbezést.[38]

Az egyház fórumkiváltsága már I. István idején kialakult. Szent István Dekrétumai Második Könyvének 3. fejezete[39] kimondta, hogy a püspökök, papok és a klérus más tagjai csak egyházi bírák által vonhatók felelösségre. Az egyházi bíráskodás különös jelentőséggel bírt azért is, mert a világi vallással, az erkölccsel összefüggö ügyek is ide tartoztak, mint ahogy a vallási elöírások teljesítése, a megrontás, az esküvel kötött ígéret, valamint a tized vitás ügyei is.[40]

A bíróságok müködésével, a bírák eljárásával kapcsolatban feltétlen szükséges megemlíteni Könyves Kálmán törvényi rendelkezését, melyben az ügy elbírálását megtagadó, vagy azzal késlekedő bírákkal szembeni szankciót határozza meg.[41] A törvény drákói szigorú, hiszen az ügy elintézésével kapcsolatban „makacskodó” bírónál elöírja, hogy a vád szerint ítéltessen. A modern büntető perjog tükrében igen különös e norma, de az adott korban nyilvánvalóan az államhatalom, a bírói hatalom megerösítését, az ítélkezés zavartalanságának biztosítását szolgálta a törvényi rendelkezés.

\subsection{A büntető perjog}

\subsubsection{Alapvetések, a perbehívás}

Az államalapítást követő századok bírósági rendszerének vázlatos áttekintése után vizsgálandó, hogy miként alakultak a büntetőjog alaki szabályai.

Az Árpád-házi királyok idején az ítélkezés államhatalmi monopóliumának joga elsődlegesen a királyé volt. Első királyaink korának büntető eljárásjogára a frank birodalom karoling korszakában kialakult szabályok voltak jelentős hatással. Ezen időszakban határozottan vádelvű (akkuzatórius) volt az eljárás, mert az alapvetően csak a sértett vádjára indult meg. Kivételt képezett azonban például a tolvajlás, mert ilyen esetekben a tiltott cselekményt elkövető feljelentése kötelező volt és az ügyeket a király követe nyomozta ki.[42] A vád a XII. század végéig szóban, majd III. Béla király[43] óta írásban volt előterjesztendő. A vádat szigorú formájú idézés követte, előkészítő eljárásra nem került sor. [44]

A perbehívás, az eljárás megindulása ténylegesen pecséttel történő idézés útján történt. Az idézés a középkorú per nagyon fontos eljárásjogi aktusa. A csak idézés útján perben állni a nemesi szabadság egyik fó ismérve volt. Az idézés különböző formái a rendi különbségeket jelezték hűen. Az idézés legrégibb formája hazánkban a pecsétküldés (missio sigilli) volt, melyről már Szent László király törvénye[45] is rendelkezett.[46]

A nemesek kizárólag szabályszerű idézés útján voltak perbe vonhatók, ellentétben a jobbágyokkal, kiket országos bíróság elé nem idéztek, hanem adott esetben a földesurat hívták fel, hogy állítsa őket bíróság elé. A perbehíváshoz mindenekelőtt perbehívó parancsra volt szükség, melyet a pert indító felperesnek az ügy elbírálására illetékes bírótól kellett kérnie. A parancs tartalmazta a peres eljárást igénylö és az idézett megjelölését, valamint azt, hogy az idézettnek hol és mely bíró előtt kell megjelennie. Az Árpád-házi királyok korában még nem volt szükséges a parancsban az ügy tárgyának megjelölése. Fontos szabály volt, hogy nemest csak birtokáról lehetett perbe hívni. Az idézési eljárás lebonyolításában un. hiteles helyek vettek rész. A perbehívás során a perben való megjelenés határnapját úgy kellett meghatározni, hogy megfelelö idő álljon a perbehívott rendelkezésére a védelme előkészítésére, mely a vizsgált időszakban feltehetően két hét volt.[47] 
Az idézés és az alapján a megjelenési kötelezettség élő perjogunknak is fontos része.[48] A felkészülés részére biztosított határidő - tárgyalási időköz - szintén a modern eljárásjog fontos eleme.[49] Az elsőfokú, a másodfokú és harmadfokú büntetőperben is kötelező szabály írja elő, hogy pontosan hány nappal korábban kell kézbesíteni az idézést az eljárási cselekménynél, mely szabályok megsértése, ha nem is feltétlen, de a védelmi jogokat lényegesen érintő relatív eljárási szabálysértésnek minősül.[50] A párhuzam természetesen nagyon távoli a középkori perjoggal, de a perbehívásnak a védelem előkészítésére biztosított határidővel kapcsolatos szabálya mégis kiemelést érdemlő hasonlóságot jelent.

A vizsgált időszakban a nemes terhelt fö szabályként szabadon védekezhetett $\mathrm{s}$ vagy mentőtanúkkal, vagy tisztító eskü, istenítélet, illetve perdöntő párbaj (baj) útján tisztázhatta magát a vádak alól.[51] A nemesi előjogok, kiváltságok már az Árpád-házi korszakban kialakultak, a nemes az Aranybullára támaszkodva védekezhetett szabadon $\mathrm{s}$ csak tettenéréskor, vagy felségsértés elkövetése esetén volt fogva tartható. Ezzel szemben a nem nemest és a jobbágyot a gyanúsításakor rendszerint azonnal letartóztatták. E személyek csak kiemelt ügyekben, mint felségsértés, hütlenség vehettek igénybe írásbeli pert. Köztörvényes büntettek elkövetésekor szóbeli procedúrának vetették alá őket, mely keretében nyomozó vizsgálat folyt, általában kínvallatás alkalmazásával.[52]

Az egyik legfontosabb, a perbehívással kapcsolatos nemesi előjogot II. András király[53] 1222. évi II. törvénycikke részleteiben is meghatározta.[54]

\subsubsection{Egyes bizonyítási eljárások}

Az alapvető normák és a perbehívás vázlatos áttekintése után az egyes bizonyítási eljárásokat, eszközöket kívánom elemezni a teljesség igénye nélkül. Az államalapítást követő első századokban a bizonyítási eljárás alapvetően formai jellegű volt. Célja nem a valóság, az anyagi igazság kiderítése, hanem a perbe hívott személy vétkességének, vagy ártatlanságának, becsületességének igazolása volt. Nyilvánvalóan az eskü vagy az istenítélet nem a múltban történt esemény valóságnak megfelelő rekonstruálására irányult, hanem formalisztikus bizonyítás útján volt hivatott tisztázni, vagy marasztalni a perbe vont személyt.

Az Árpád-házi királyok uralkodásának első részében, hasonlóan Európa más államaihoz, az egyik legfontosabb bizonyítási eljárás az istenítélet volt, mely elsősorban próbák által igazolta a vád alá helyezett ártatlanságát, vagy vétkességét.

Már Szent László és Kálmán törvényei megállapítottak olyan eseteket, amikor a bíróságnak próbákat kellett alkalmazni. Ezek valamennyien vagyoni viszonyokat sértő, tolvajlási ügyek voltak, melyeknél a próba neme nem volt törvényben megjelölve. Két kivételt lehet azonban említeni. Lólopás és hamis tanúság vádja esetén a törvények határozottan a tüzes vaspróba alkalmazását írták elő.[55]

Kiemelést érdemel e körben I. László király Dekrétomai Második Könyvének 28. fejezete, melyben lényeges bizonyítási szabályok kerültek meghatározásra az istenítélettel kapcsolatos próbákat (víz és vaspróba) illetően, mely során hiteles személyek tanúként eljárását írták elő az ártatlanság, vagy az elkövető vétkességének bizonyítása során.[56] A vizsgált korszak elején a már idézettek szerint az eljárás alá helyezett személy vétkességét, vagy ártatlanságát rendszerint mentő tanúkkal, később tisztító esküvel, istenítélettel vagy bajvívás által tisztázták. Az istenítélet, a próbák fontosságát jelzi az idézett királyi dekrétum, mely a bizonyítási eszköz deklarációja mellett részletszabályokat is alkotott. A törvényi szabályozásból is látható, amint Hajnik is utalt rá, hogy a vaspróbát a vízpróbánál súlyosabbnak tartották, mely megállapítást megerősít, hogy utóbbi díja a másiknak csak a fele volt.

A próba odaítélésekor a bíróság megjelölte annak helyét is. Kálmán törvényei szerint ennek színhelye csak székesegyház, vagy nagyobb prépostsági egyház lehetett. A fennmaradt 
források szerint próbákat végeztek Nagyváradon, Pozsonyban, Nyitrán, valamint Kalocsán, Egerben, Budán és Aradon.[57] Az állami és egyházi hatalom szerves egységét, az egyház igen jelentős befolyását, világi hatalmát jelzik a büntető perjog idézett szabályai is, hiszen az egyház nem vallási tárgyú ügyekben is központi szerepet játszott a büntetőperben az istenítéletek lebonyolításában való közremüködéssel.

Kálmán király uralkodása után már csak a vaspróbákat alkalmazták, melynek fö történeti emléke a váradi regestrum, ami dokumentálja a nagyváradi egyháznál végzett vaspróbák jegyzékét. Az ilyen jellegü istenítéletre döntően büntetöügyekben került sor. E próba egyoldalú volt, bünügyekben kivétel nélkül az alperesnek, azaz a vádolt félnek kellett magát személyesen tisztáznia. A próbát rendszerint az egyházban hajtották végre. A próba alakiságát már a korszak első részében törvény szabályozta, a már idézett, I. László által hozott dekrétum, mely három tanú jelenlétét kívánta meg a próba során.[58] A tüzes vaspróba eszköze egy 1-3 fontos vas volt, melyet egyházi módon felszenteltek. A próba elvégzése előtt a vasat felizzították és ünnepélyes keretek között megáldották. Az ártatlansága kinyilatkoztatása után a vádolt, próbára kötelezett fél az izzó vasat felmarkolta és a templom egy másik helyére vitte. A próba eredményét az határozta meg, hogy az izzó vas megégette vagy épen hagyta a fél kezét. Ezt azonban nem nyomban, a próba napján, hanem a kéz begöngyölése és egyházi pecséttel való ellátása után néhány nappal állapították meg a pecsételt göngy levételét követően. Ha a kéz sérült, égett volt, akkor a próba igazolta a fél vétkességét $\mathrm{s}$ ő megégettnek (combustus) volt tekintendő. Ellenben ha a kéz épen maradt, az az ártatlanságát bizonyította, a fél tisztáztatott a vádak alól (mundatus).[59] A bizonyítás jellegéből eredően megállapíthatjuk, hogy a vaspróba egyértelmüen olyan formális, szakrális elemeket hordozó alaki bizonyítás, mely igen távol áll a modern perjognak a valóság feltárására, vagy az anyagi igazság kiderítésére irányuló bizonyítási eljárásaitól. Az izzó vas megragadása feltehetően égési sérüléseket okozott a próbának alávetett fél kezén. Nyilvánvaló, hogy az érintett egészségi állapotán, gyógyulási képességén, bőrének speciális jellegzetességein múlt, hogy a próba ellenőrzésekor égést igazoltak, vagy a kéz épségét. A vizsgált korszakban az eredmény megjelenésében isten ítéletét látták s a bizonyítás formájából adódóan ez volt a döntő, nem pedig a valós tények annak megállapításakor, hogy a vádolt vétkes vagy ártatlan.

Utalni kell rá, hogy a próba el is maradhatott, ha a felperes elismerte vádjának alaptalanságát, vagy pedig ha a felek kiegyeztek. A próba végkimeneteléig, a göngyölt kéz megvizsgálásáig ennek mindig helyt adtak. A XIII. század második felétől a források már nem szólnak a próbákról. Az istenítélet, mint bizonyítási eljárás megszünése feltehetően az 1279-es, Budán tartott zsinathoz füződik, melynek nyolcadik cikke megtiltotta, hogy a papság a próbákkal való tisztázásnál, annak eszközei megáldását, megszentelését teljesítse. A próbaeljárás központi, szakrális szabálya volt az áldás az egyházi helyszínen, ezért az egyházi tilalom feltehetően rövid időn belül megszüntette az istenítéletek e formáinak a bizonyítási eljárásban való jelenlétét.[60]

A baj, másként nevezve párbaj (duellum) az az istenítélet, mely legtovább maradt fenn a gyakorlatban hazánkban. A büntető perjogban a szorosan vett próbáknál, tehát víz - és vaspróbánál a párbaj később jelent meg. A XIII. század előtt a források még nem utalnak rá, a próbának az egyházi tilalmazás folytán történő megszünését követően azonban a baj egyre fontosabb szerepet kapott a bizonyításban. A bajvívásra nem csak felsőbb bíróságok, hanem a megyék, városok bíróságai és kiváltságos felségek bíróságai is ítélhettek. A jogfejlődés során az Ârpád-házi korszak után, a XIV. század közepétől azonban a baj mindinkább a felsőbíróságokra, valamint a megyékre szorult vissza.[61] A bajvívást egyrészt a bíró saját hatáskörében, önhatalmúlag rendelhette el, de bizonyos esetekben köteles volt azt elrendelni. Ilyenek voltak a nagyobb súlyú bünügyek, mint a felségsértés, a hütlenség, a pénzhamisítás, a gyilkosság, vagy a gyújtogatás.[62] A ma élő, hatályos büntető perjog és a 
jogalkalmazó számára az istenítélet, a párbaj már nyilvánvalóan jogtörténeti emlék. Megjegyzendő azonban, hogy az ügyek bizonyos formájú csoportosítása, elkülönítése, kiemelt jellegüvé tétele a jogfejlődés során a perjogi kódexekben fennmaradt. Gondolhatunk itt például a hatályos büntetőeljárási törvényünk kapcsán a törvényszéki hatáskörbe tartozó, legsúlyosabb megítélésü ügyekre,[63] vagy akár a kiemelt jelentőségü ügyek[64] speciális szabályaira. Az emberi élet kioltásával járó, vagy az államhatalmat sértő, veszélyeztető cselekmények a büntetőeljárásban mindig kivételes szabályok szerinti elbírálást igényeltek, mely megnyilvánul a bírói hatáskör telepítésében, valamint a bizonyítási eljárás speciális szabályaiban is.

Visszatérve a párbaj szabályaira, a bünügyben végzett próbától eltérően azt nem feltétlen személyesen kellett vívnia a félnek. Súlyos bünesetekben azonban a bíróság kötelezhette a felet a személyes bajvívásra. Rendszerint azonban a peres felek nem személyesen vívták a bajt, hanem bajnok (duellator) útján. A vívás fó módjai a lovas és a gyalog baj volt, melynek lebonyolítását természetesen befolyásolta a használható fegyverzet is. A bajra a bíró által kitüzött helyen és időben került sor. A bajvívásnak perdöntő ereje volt, ami abban nyilvánult meg, hogy a párbajban elbukott fél a perét végleg elvesztette.[65] Ezen istenítélet a végkimenetelt tekintve hasonló a próbákhoz, amelyek eredménye szintén érdemben és véglegesen lezárta a pert.

A próbák megszünése, a párbajok visszaszorulása, valamint az érintett időszakban az okmánybizonyítási lehetőségek szűk volta miatt nagy jelentőségüvé váltak az eskük, melyek alapján kerültek eldöntésre az ügyek. Mit is jelent az eskü? Amint Hajnik Imre kifejtette, az eskü a perben tett állításnak, vagy tagadásnak az Istenségre való hivatkozással való megerősítése.[66] Az eskü szorosan kapcsolódik a tanúbizonyításhoz. A tanúbizonyítás ugyanis a vizsgált korszakban nem bírt perdöntő erővel. A tanúbizonyítás ezért mintegy előzetes bizonyítási eljárás jelent meg, melyhez, vagy az ellen esküre vagy istenítéletre volt szükség. A tanúbizonyítás e korszakban még alapvetően alaki természetű volt, mely csak a XIII. század végétől vált anyagivá a vallatás megjelenésével.[67] Az alaki tanúbizonyítás, tanúság (humanum testimonium) lényege az volt, hogy a tanú az egyik fél oldalán és érdekében lépett fel. A szerepe a fél állításainak, szavahihetőségének megerősítése. A bizonyítási erő e korszakban még magában a tanú személyében és az általa a fél mellett tett esküjében jelent meg, nem pedig a vallomásban.[68] E körben feltétlen szükséges utalni Könyves Kálmán dekrétumára, mely a tanúságtevő gyónását írta elő a vallomástétel elött.[69] A tanúbizonyítással kapcsolatos fontos elv fogalmazódik meg I. István király Második Dekrétuma már idézett 3. fejezetének 1. §-ában, amely a tanúkkal és vádlókkal szemben támasztott erkölcsi, vallási feltételeket rögzítette.[70] A modern, élő jogban, a tanú vonatkozásában természetesen ilyen vallási, erkölcsi követelményeket már nem támaszt a jogalkotó. A tanúvallomásnál mégis érdemes említeni a legjobb tudás és a lelkiismeret szerinti vallomástételi kötelezettséget, mely a hatályos perjog fontos szabálya és megítélésem szerint a tanú hitelességének korai középkori elvárásával hasonlóságot mutat.[71] A hasonlat meglehet távoli, de úgy vélem a modern büntetőeljárás is fontos hangsúlyt helyez a tanúvallomás hitelt érdemlősége megítélésénél a tanú személyére, személyiségére. Nyilvánvalóan egy többszörösen büntetett, rovott múltú egyén, különösen a hatósággal alku reményében tanúskodó zárkatárs tanúvallomását egy büntetöügyben fokozott gondossággal kell értékelni, míg egy törvénytisztelő, állami alkalmazott, vállalkozó, gazdálkodó vagy egyházi személy tanúvallomásának hitelességével szemben kevésbé merülnek fel aggályok. Ami természetesen nem azt jelenti, hogy utóbbi személyek vallomása minden esetben megfelel a valóságnak, az igazságnak, de a bíró a tanú társadalmi státuszát, személyét rendszerint nem hagyja figyelmen kívül. Nem volt ez másként már a középkorban sem, természetesen más törvényi háttérből és jogalkalmazói szemléletből fakadóan. 
A már idézettek szerint az Árpád-kori tanúbizonyítás formai jellegű volt és a XIV. századtól a magyar perjogból, annak mint rendes alkatrésze kiveszett, s helyébe a tanúbizonyítás új formája, a tanúvallatás (inquisitio) lépett, mely bizonyítás szerves részét képezték a tudományvételi eljárások. E jogintézmények azonban már alapvetően az Árpád-házi korszak vége után, a vegyes-házi királyok uralkodása alatt alakultak ki, ezért elemzésük nem képezi a tanulmány tárgyát.

A hatályos perjogban igen fontos bizonyítási eszköz az okirat. Az okirati bizonyítás már a hazai büntető perjog fejlődésének korai időszakában megjelent. A királyság első két évszázadában az ország lakosainak jogai csak ritkán voltak okiratokba foglalva. A XI-XII. században csak a királyi okiratokat tekintették olyan közokiratnak, melynek teljes hitelt adtak. Az okirati bizonyítás fejlődésének fontos állomása a per anyagának írásos rögzítése. III. Béla óta jegyzőkönyvet készítettek a tárgyalásról, a király ugyanis elrendelte, hogy minden eléje kerülő ügyet írásban dokumentáljanak. Ezt követően megnőtt az oklevelek szerepe is a bizonyításban. Az Árpád-házi királyok korában elsődlegesen a király pecsétjével ellátott okiratok bírtak bizonyító erővel. Úgy gondolom, hogy a büntetőügyekben az okirati bizonyítás az érintett időszakban nem volt meghatározó, a főbb bizonyítási eljárások ekkor az istenítéletek és az eskü voltak. A hiteles oklevelek azonban már megjelentek az Árpád-házi királyok uralkodása alatt, de úgy vélem a bizonyításban a vagyonjogi, birtokperekben kaptak hangsúlyt s nem a büntető igazságszolgáltatásban.

\subsection{3. Ítélet a perben}

$\mathrm{Az}$ ítélethozatalhoz vezető tárgyalás, amint Angyal Pál kifejtette a nyilvánosság, a közvetlenség és a szóbeliség elvei szerint folyt azzal, hogy a már idézettek szerint III. Béla király óta a tárgyalásról jegyzőkönyvet vettek fel. Ha a felek nem egyeztek ki, amire magánegyén sérelmére elkövetett lopás kivételével mindig volt lehetőség, a bíróság ítéletet hozott.[72]

A bírói hatalom döntése az ítéletben jelent meg. Az ítéletet, amint láthattuk, bizonyítási eljárás előzte meg, mely az Árpád-házi kor büntető perében alapvetően az istenítéletekre (próbák, baj) és az esküre épült. E bizonyítási eljárások perdöntőek voltak, a bírói mérlegelésnek, a bizonyítási anyag szabad értékelésének ilyen jellegü eljárásban helye nem volt. Az istenítéletek elvégzését követően a bíróság a jogvitát rendszerint végítélettel (sententia) döntötte el, mely elmarasztaló, vagy felmentő lehetett. A bünvádi perben a konkrétan szabályozott fó ítéleti formák (fejvesztési ítélet, fejváltsági ítélet, becstelenségi ítélet) a vegyes-házi királyok idején alakultak ki. Megállapítható azonban, hogy már az Árpád-házi korszak végén, személyen és vagyonon elkövetett erőszakoskodás miatt a királynál kerestek orvoslást. A király ilyen esetben kutatást rendelt el és ennek eredményéhez képest ítélt. A források ugyanakkor kifejezetten nem utalnak fejvesztésre, csak Károly Róbert király korában került sor az erőszakoskodások bírói úton való szabályozására, mely normák szerint a sértett fél panaszára általában fej és jószágvesztés terhével lehetett sújtani az elkövetőt.[73] Az Árpád-házi kor büntetőperében magáról az ítéletről, ítéleti formákról kevés hiteles dokumentum maradt fenn, úgy gondolom azonban, hogy az érintett korszak végén a királyi kutatást követően feltehetően alkalmazták a fejvesztést, másképp fogalmazva a megtorló jellegü halálbüntetést.

Az ítéletet a bíróságtól kellett kérni s azt a bíróság hozta meg. Az elemzett korszak elején az ítéletet még nem foglalták okiratba. Kezdetben az egyház készített feljegyzéseket ítéletekről, majd később a felek a király pecsétjét kérték a döntés megerősítéséül. A már felhívottak szerint a per anyagának írásba foglalását III. Béla rendelte el. A XIII. században pedig már más magasabb bírák, mint a nádor, bán, vajda, föpapok is rendszeresen állítottak ki ítéleteikről bizonyságlevelet.[74] 


\subsubsection{A jogorvoslat kérdései}

A modern értelemben vett jogorvoslatról az Árpád-házi királyok idején folytatott büntetőperek kapcsán nem beszélhetünk. A kérdés megvizsgálásakor elsődlegesen fel kell tennünk a kérdést, hogy mit is jelent a jogorvoslat. Amint Cséka Ervin szemléletesen rámutatott, a jogorvoslat a már bekövetkezett eljárási tévedések, helytelen, törvénysértő határozatok orvoslása annak érdekében, hogy a hibás döntés jogkövetkezményei lehetőleg ne álljanak be, illetőleg mielöbb megszünjenek, s az új, helyes, a törvénynek megfelelö döntés kerüljön az előző helyébe.[75] A fogalom meghatározás nyilvánvalóan a modern kor büntetőperét tekintve írja le a jogorvoslat lényegi elemeit.

Az árpádkori perjog az eljárásban alapvetően a felek saját tevékenységére, az alakszerüségek szigorú betartására fektette a hangsúlyt, mely jól nyomon követhető az istenítéletek szakrális elemekkel kísért részletszabályaiból is. A felek perbeli mulasztásainak, tévedéseinek orvoslására nem kerülhetett sor. Csak ha a bíróság nem akart igazságot szolgáltatni, vagy a megszabott alakiságokkal szemben járt el, akkor az igazságszolgáltatás megtagadása miatt lehetett a királyhoz fordulni, aki a bírót az udvarba idézve szolgálhatott orvoslást.[76] Emellett előfordult, hogy a bíróság, ha kételyei voltak, vagy az ügyet súlyosnak ítélte, a pert a királyhoz tette át. Láthatjuk tehát, hogy nem a bírói döntés maga, lényege, tartalma volt támadható, hanem a bíróság mulasztásában, „makacskodásában”[77] megnyilvánuló jogsértés. A modern, a hibás döntés elhárítását célzó jogorvoslat korszakbeli kialakulását értelemszerüen gátolta a döntéshez vezető folyamat jellege, a bizonyítási eljárás perdöntő jelentősége. Az istenítéletek ugyanis kötelező erővel határozták meg a bíróság döntését. Az egyház által megáldott vaspróba, vagy a párbaj eredménye ugyanis kötötte a bírót, aki a bizonyítást érdemben nem mérlegelhette, az isteni akarat megjelenése nem volt felülbírálható.

A klasszikus értelemben vett perorvoslatok csak később, a vegyes-házi királyok idején alakultak ki, részben szokásjogi alapon. Így jelentek meg a XIV-XV. században a per letétele, az ügyvédszó visszavonása, a tiltakozások a perben, a fellebbezés, az elüzés, majd végül a perújítás.

\section{Zárszavak}

Amint láthattuk a bírósági rendszer és az írott normák által szabályozott per, a büntető igazságszolgáltatás az államalapítást követő évszázadokban alakult ki. Igen nagy jelentősége volt a korai Árpád-kor királyai által kibocsátott törvényeknek, melyek lényeges anyagi jogi szabályok mellett kitértek eljárásjogi kérdésekre is. A vizsgált korszakban értelemszerüen kodifikált büntetőeljárásról nem beszélhetünk, de már megjelentek olyan peralkatrészek, melyek egyes elemei, ha jelentős változások után is, de fennmaradtak a jogfejlődés során és jelen vannak a modernkor büntető perjogában is. I. István, I. László, Könyves Kálmán, III. Béla és II. András törvénykezése nemcsak a magyar államtörténetnek, de a jogfejlődésnek, a büntető igazságszolgáltatásnak is talpkövei. Amint Balogh Jenő és Angyal is megállapította a XIX. század végére kodifikált büntető perrendtartás[78] nem a régi magyar jogfejlődés eredménye, hanem a jelzett század folyamán kifejlődött kontinentális vegyes rendszeren alapul.[79] Értelemszerüen a jelenleg hatályos perjog sem a magyar jogtörténet évezredes változásaira épül. Ettől függetlenül mindenképp indokolt és tanúságos visszatekinteni az államalapítást követő évszázadok büntető igazságszolgáltatására, mely ugyan a mai társadalmi viszonyokhoz képest merőben más környezetben alakult ki, tartalmaz azonban olyan elveket, melyek az élő jognak is részei. Gondolhatunk e körben magára a büntetőügy eldöntésének fórumára, a tárgyalásra, annak nyilvánosságára, vagy az eljárási cselekmények jegyzőkönyvezésére, mely III. Béla rendelkezése nyomán már a XII. század végén 
megjelent. A magyar jogfejlődéstől tehát eltérő formában alakult ki ugyan a hazai modern büntetőper, de úgy vélem sosem lehet cél nélküli, vagy haszontalan a jogtörténeti elemzés, hiszen történetünk, a történelem ma is tanít minket, ekként a modern büntető perjog müvelöje is hasznos ismereteket szerezhet a korai forrásokból.

\section{Die ungarische Strafjustiz in den ersten Jahrhunderten nach der Staatsgründung im Spiegel der römischen und europäischen Rechtsentwicklung - Zusammenfassung}

Der Aufsatz stellt die Strafjustiz der ersten Jahrhunderte nach der ungarischen Staatsgründung, des Zeitalters der Könige aus dem Hause Árpád im Spiegel der römischen und westeuropäischen, besonders der fränkischen Rechtsentwicklung vor. Er untersucht neben der Entstehung des ungarischen Gerichtssystems die Ordnung des Strafverfahrens, eingehend auf die Ladung, die Beweisverfahren, besonders die Gottesurteile, den Gerichtsbeschluss und den Rechtsbehelf.

Die Arbeit ist rechtsgeschichtlichen Inhalts, aber wo es möglich ist, und Parallelen gezogen werden können, vergleicht sie solche Einrichtungen des ehemaligen und modernen Rechts miteinander, die während der Rechtsentwicklung unverändert Teil des Strafprozesses geblieben sind.

Dem einleitenden Teil folgend geht sie als Erstes auf den Begriff und Zweck des Strafverfahrens ein; diesen Zweck definiert sie nach den literarischen Quellen als die Belangung der die Staatsordnung verletzenden Person.

Auf die geschichtliche Entwicklung besonders des Zivilrechts, aber auch des Strafrechts hatten die römisch-rechtlichen Wurzeln großen Einfluss. Der Aufsatz bietet einen Überblick über die organisatorischen und prozessualen Grundlagen der römischen Strafjustiz, sowie die einzelnen Straftaten und die ihre Beurteilung regelnden Normen. Es wird betont, dass bereits im römischen Recht solche konstitutionelle, den europäischen Standards entsprechende Prinzipien zur Geltung kamen, wie die Öffentlichkeit der Verhandlung oder das Recht auf Verteidigung.

Nach der Analyse der römisch-rechtlichen Grundlagen wird die Entwicklung des mittelalterlichen europäischen Strafrechts untersucht. Die Rechtsgeschichte, die Rechtsentwicklung Kontinentaleuropas hatte bedeutenden Einfluss auf die Regeln des ungarischen Strafprozessrechts. Besondere Hervorhebung verdient in diesem Teil das Recht des Fränkischen Reichs.

Nach der Beleuchtung des europäischen strafrechtlichen Hintergrunds analysiert der Aufsatz die Strafjustiz der Könige aus dem Hause Árpád. Er stellt die Entwicklung des Gerichtssystems, die Rechtsprechung durch den König, dann durch die Großwürdenträger, die Entstehung des ordentlichen Gerichtssystems und der Gerichte auf dem Land vor, hinweisend darauf, dass bereits zu Anfang der Herrschaft der Könige aus dem Hause Árpád solche wichtigen königlichen Dekrete erlassen wurden, die die Entwicklung des Strafrechts wesentlich bestimmt haben.

Nach dem Überblick des Gerichtssystems untersucht die Arbeit einzelne wichtige Rechtsinstitute des Strafprozessrechts. Eine solche grundlegende Einrichtung ist die Beiladung, die der Ladung des modernen Rechts entspricht. Die Adeligen konnten ausschließlich durch ordnungsgemäße Ladung beigeladen werden, im Gegensatz zu den Leibeigenen, in deren Strafsachen der Gutsherr aufgerufen wurde, sie vor Gericht zu stellen. 
Sehr wichtige Rechtsinstitute des Strafverfahrens sind des Weiteren die einzelnen Beweisverfahren, die anfangs in Gottesurteilen sakraler Charakter wie den Proben beziehungsweise dem Zweikampf in Erscheinung traten. Neben den Gottesurteilen können als weitere Beweisverfahren der Reinigungseid sowie der formelle Zeugenbeweis erwähnt werden, aber schon früh bekannt war auch der Urkundenbeweis.

Der Aufsatz unterzieht die Urteilsfindung im Prozess separat einer Untersuchung, hervorhebend, dass im Verfahren gegen den Adeligen die Öffentlichkeit zur Geltung kam, seit König Béla III. wurde über die Verhandlung sogar Protokoll geführt. Um ein Urteil musste das Gericht ersucht werden, und es wurde vom Gericht gefällt.

Die Arbeit berührt schließlich einzelne wichtige Fragen des Rechtsbehelfs mit der Bemerkung, dass vom Rechtsbehelf im modernen Sinne genommen im Zeitalter der Könige aus dem Hause Árpád noch nicht gesprochen werden kann. Das Rechtsmittel zielte zu dieser Zeit noch nicht auf die Beseitigung der Fehlentscheidung, sondern konnte die Justizverweigerung seitens des Gerichts oder gewisse Formwidrigkeiten beanstanden.

„Iustitia est regnorum fundamentum”[1]

* Bíró, Debreceni Ítélőtábla, a DE ÁJK Büntető Eljárásjogi Tanszék meghívott óraadója.

[1] A jog az országok talpköve

[2] IRK Albert: A magyar anyagi büntetőjog. Dunántúli Egyetemi Nyomda, Pécs, 1928, 229.

[3] Angyal Pál: A büntetőeljárásjog tankönyve I. Atheneaum Kiadó, Budapest, 1915, 1.

[4] ERDEI Árpád: Tanok és tévtanok a büntető eljárásjog tudományában. ELTE Eötvös Kiadó, Budapest, 2011, 24.

[5] STEIN, Peter: A római jog Európa történetében. Osiris Kiadó, Budapest, 2005, 10.

[6] SzABÓ Béla: Előadások a római állam- és jogtörténet köréből. Bíbor Kiadó, Miskolc, $1998,85$.

[7] Az elv a megtorlás mértékét elöre meghatározta.- HT.

[8] BRósz Róbert - PólAY Elemér: Római jog. Hatodik kiadás. Tankönyvkiadó, Budapest, $1991,457$.

[9] STEIN: i.m. 14-18.

[10] BRÓSZ - PÓLAY: i.m. 458.

[11] Láthatjuk, hogy már az ókori Rómában is kialakult a bíráskodás olyan formája, ahol az állam szolgálatában álló közhivatalnok végezte az igazságszolgáltatást. A korai középkorban nem vitásan történt visszalépés, mert az ítélkezés joga kezdetben kizárólag a királyé volt, aki később azonban delegálta hatalmát a főméltóságoknak, majd a jogfejlődés ismét visszatért a hivatalnoki bíráskodás útjára. - HT.

[12] BRÓSZ - PÓLAY: i.m. 458.

[13] Si nix furtum faxcit, si im occisit, iure caesus esto. XII. táblás törvény VIII.12. Lásd még BRÓSZ-PÓLAY: i.m. 462.

[14] XII. táblás törvény VIII.2.

[15] Lex Aquilia (Kr.e. 286.)

[16] Lásd 2012. évi C. törvény ( a továbbiakban Btk.) 365. § (1), (2) bekezdését.

[17] BRÓSZ - PÓLAY: i.m. 462-465.

[18] E büntetésfogalom, a latin megnevezéssel napjainkig fennmaradt, gondoljunk itt a nulla poena sine lege alapvetö elvre, mely szerint törvény nélkül nincs büntetés, azaz csak olyan büntetés szabható ki az elkövetővel szemben, melyet az elkövetéskor a büntető törvény már 
meghatározott. Ez kardinális alapelve az anyagi büntetőjognak, szorosan kapcsolódva a nullum crimen sine lege elvéhez. - HT.

[19] BRÓSZ - PÓLAY: i.m. 460-461.

[20] Btk. 322. § (közveszély okozása), Btk. 290-292. § (vesztegetés)

[21] BRÓsZ - PÓlAY: i.m. 466-467.

[22] A hamisításokat a lex Cornelia de falsis minösítette büncselekményeknek.

[23] Lásd: lex Cornelia de sicariis et veneficiis.

[24] Lésd: lex Julia Adulteris

[25] BRÓSZ-PÓLAY: i.m. 466-467.

[26] ANGYAL: i.m. 15-16.

[27] GÖNCZI-HORVÁTH-RÉvÉSZ-STIPTA-ZLINSZKY: Egyetemes jogtörténet I. Nemzeti Tankönyvkiadó, Budapest, 2006, 103-109.

[28] Martell Károly unokája, Kis Pipin fia, frank császár (742-814.)

[29] A FARKAS-RÓTH szerzőpáros is rámutatott arra, hogy a nyomozó rendszerü eljárás az 1215-i lateráni zsinat után szilárdult meg és terjedt el később néhány évszázad alatt Európában. Lásd: Farkas Ákos - Róth Erika: A büntetőeljárás. Complex Kiadó, Budapest, 2012, 35.

[30] ANGYAL: i.m. 16-18.

[31] ANGYAL: i.m. 26.

[32] STIPTA: i.m. 16.

[33] Szent István Király Dekrétomainak Második Könyve, 16. Fejezet a szándékos emberölésről: Ha valaki haragra gerjedvén és felfuvalkodván kevélységgel, szándékos emberölést követ el, tudja meg, hogy száztiz arany pénzt fizet érte, a mint a mi tanácsunk végezte. 1. § Ebből ötvenet a király kincstárába vigyenek, a más ötvenet adják a rokonoknak, tize pedig az itélőbiráké és közbenjáróké legyen. És maga a gyilkos bőjtöljön a kánonok rendelése szerint.

[34] Szent István Király Dekrétomainak Második Könyve, 46. Fejezet azokról akik karddal ölnek embert: Valaki embert öl karddal, azon kard által vesszen el.

[35] Szent István Király Dekrétomainak Második Könyve, 49. Fejezet arról, aki kardot von, de sebet nem ejt: Ha valaki dühe gerjedelmében kardját kivonja, de mindazáltal sebet nem ejt vele, csupán a mezitelen kardért bünhödjék a vérdíj felével.

[36] ANGYAL: i.m. 26.

[37] STIPTA: i.m. 17.

[38] ANGYAL: i.m. 26-27.

[39] Szent István király Dektéromainak Második Könyve, 3. fejezet 2. §: És senki valakit a papok közül nyilvánságosan vallatni nem bizakodjék, hanem csak az egyház elött.

[40] STIPTA: i.m. 17.

[41] Kálmán Király Dekrétomainak Első könyve 10. Fejezet a bírák makacskodásáról, mikor a zsinatra menni nem akarnak: Ha valamely biró a mondott zsinatra való menetelt makacsul elhelyélné, ítéljék meg a vád szerint.

[42] Kálmán Király Dekrétomainak Első Könyve 51. Fejezet arról, hogy a tolvajokat negyed napra állassák a törvény eleibe, és ennek módjáról: Aki tolvajt fog, három napon által tartsa megkötözve, keze szárasztása és tüzzel égetése nélkül, negyed napra pedig vigye biro elibe. 1.§ Mikor a tolvajt az ő urának poroszlója viszi, ha csak egy háznép vagyon is ottan, egyikük menjen a tolvajjal, és ha nem akar, a biro nem féljen itélnie. 2. § De ha ottan semmi házbeli nép nincsen, küldje a biro a megkötözött bünöst azon urnak valamely közelebb fekvő birtokára és itélje meg törvény szerint.

[43] III. István fiát, a Bizáncban nevelkedett III. Bélát 1173-ban koronázták királlyá és 1196ig uralkodott

[44] ANGYAL: i.m. 27. 
[45] Szent László Király Dekrétomainak Harmadik Könyve 3. Fejezet a nádorispánról és az ő pecsétjéröl és hatalmáról: Tetszett azt is végeznünk, hogy mikor a nádorispán haza megyen, a király és udvara pecsétjét annál hagyja, ki az ő helyén leszen, hogy valamint egy a király udvara, azonképen pecsétje is egy legyen. 1 . § Valamig pedig azon ispán otthon leend, senkire pecsétjét ne küldje, hanem csak azokra, kik udvarnokoknak hivattatnak; és a kik szabad akaratjokból járulnak eleibe, azokon legyen hatalma itélnie. 2. § Ha máskülönben cselekszik, ötvenöt pénzt fizessen. 3. § Hasonlóképen a herczeg ispánja is, ha mást mint ki alatta vagyon, megitél, ugyanazon törvénynyel fenyittessék.

[46] HAJNIK Imre: A magyar bírósági szervezet és perjog az Árpád-és vegyes-házi királyok alatt. Budapest, Magyar Tudományos Akadémia, 1899, 186.

[47] HAJNIK: i.m. 191.

[48] Be. 67. § (1) bekezdés: Ha e törvény kivételt nem tesz, a bíróság, az ügyész, a nyomozó hatóság azt idézi, akinek jelenléte az eljárási cselekménynél kötelező.

[49] Be. 279. § (3) bekezdés, 364. § (2) bekezdés, 393. § (3) bekezdés

[50] Be. 375. § (1) bekezdés

[51] ANGYAL: i.m. 27.

[52] DoвOs József: A büntetőeljárás történeti fejlődésének vázlata az 1896-os első kódexig. Jogelméleti Szemle 2003/3., 1.( http://jesz.ajk.elte.hu/dobos15.html, letöltés: 2013. november 4.)

[53] (1205-1235)

[54] II. András, 1222. évi II. törvénycikk arról, hogy hogy senki perbehivás nélkül el ne marasztassék: Ezt is akarjuk, hogy a nemes embert sem mi, sem az utánunk való királyok soha meg ne fogják vagy meg ne nyomorítsák valamely hatalmas kedveért, hanem ha előbb perbe hivatott és rendes uton törvényt láttak reá.

[55] HAJNIK: i.m. 252.

[56] I. László Dekrétomainak Második könyve 28. Fejezet a tüzes vas és forró víz próbájánál való tanuságról: Valahányszor vizzel vagy vassal való itélettel leszen, legyen ott három alkalmatos tanú, hittel próbált emberek, akik mind az ártatlanok ártatlanságát, mint pedig a vétkesnek a vétkét bizonyitsák. 1 . $§$ A vastól két pénz, a viztől egy pénz járjon a papnak.

[57] HAJNIK: i.m. 255.

[58] I. László II. 28.

[59] HAJNIK: i.m. 257.

[60] HAJNIK: i.m. 258.

[61] HAJNIK: i.m. 260.

[62] HAJNIK: i.m. 262.

[63] Be. 16. §

[64] Be. XXVIII/A. Fejezet

[65] HAJNIK: i.m. 271-272.

[66] HAJNIK: i.m. 276.

[67] HAJNIK: i.m. 277.

[68] VADÁSZ Viktor: A tanúbizonyitás rendszere a középkori magyar büntetöeljárásban. Iustum Aequum Salutare VII. 2011/3. 144.

[69] Kálmán Király Dekrétomainak Első Könyve 26. Fejezet arról, hogy a tanuk gyónjanak meg, minekelötte tanuságot tesznek: Parancsoljuk, hogy ha valaki tanuságra hivatik és az ö vallomásával másnak az igazságát akarja megbizonyitani, ily okkal fogadják el annak tanuságtételét: elsőben is, ha meggyónta büneit a papnak, azután, ha földje van; azért, hogy a gyónás legyen zálog az igaz tanuságért, a birtok pedig váltság a hazug tanu vétkeért.

[70] Szent István Király Dekrétomainak Második Könyve 3. Fejezet, milyenek legyenek a vádlók meg a tanuk? 1. §: Legyenek pedig a tanuk és vádlók minden gyalázat foltja nélkül való, feleséges és családos emberek és mindenestől fogván Krisztus követői. 
[71] 1998. évi XIX. törvény (Be.) 85. § (3) bekezdés

[72] ANGYAL: i.m. 28.

[73] HAJNIK: i.m. 389.

[74] HAJNIK: i.m. 397.

[75] CsÉKA Ervin: A büntető jogorvoslatok alaptanai. Közgazdasági és Jogi Könyvkiadó Budapest, 1985, 31.

[76] HAJNIK: i.m. 411.

[77] Vö. Könyves Kálmán Dekrétomai nak Első Könyve 51. Fejezet

[78] 1896. évi XXX. évi tv. a bünvádi perrendtartásról (Bp.)

[79] ANGYAL: i.m. 25. 